IN THE SHADOW OF THE MAMMOTH

Italo Svevo and the Emergence of Modernism 
This page intentionally left blank 


\section{IN THE SHADOW OF}

\section{THE MAMMOTH}

\section{Italo Svevo and the}

Emergence of Modernism

Giuliana Minghelli 


\section{www.utppublishing.com}

(C) University of Toronto Press Incorporated 2002

Toronto Buffalo London

Printed in Canada

ISBN 0-8020-3638-4

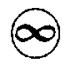

Printed on acid-free paper

Toronto Italian Studies

\section{National Library of Canada Cataloguing in Publication}

\section{Minghelli, Giuliana}

In the shadow of the mammoth : Italo Svevo and the emergence of modernism / Giuliana Minghelli

Includes bibliographical references and index.

ISBN 0-8020-3638-4

1. Svevo, Italo, 1861-1928 - Criticism and interpretation.

2. Symbiosis (Psychology) in literature. 3. Modernism (Literature) Italy. I. Title.

PQ4841.V4Z754 2002 $853^{\prime} .8 \quad$ C2002-902951-1

University of Toronto Press acknowledges the financial assistance to its publishing program of the Canada Council for the Arts and the Ontario Arts Council.

University of Toronto Press acknowledges the financial support for its publishing activities of the Government of Canada through the Book Publishing Industry Development Program (BPIDP). 
All'ombra di mio padre 
This page intentionally left blank 